\title{
Accountability Asset Recovery: A Leadership \& Sustainability Initiative Receivership Is NOT Releasership
}

\author{
Monika L. Sheldon-London \\ Alpha FTS \\ University of Malta \\ University of Cumbria UK \\ Robert Kennedy College Zürich \\ Student Public Leadership Credential Harvard Kennedy School
}

\begin{abstract}
For effective recovery of qualified assets, receivership is not releasership--the improper disposition of recovered assets. Disposition of assets being the technical terminology utilized by asset recovery and insolvency practitioners to motion the court to release recovered assets held in their custody. According to the IMF, insolvency practitioner overreach has become macro-critical to the stability of the global financial system. Anti-money laundering, countering the financing of terrorism, preventative measures and the proceeds of crime acts, 2003 and 2009 for the common law legal system and 2005 for the civil law legal system under pinning AML-CFT international cooperation could have become captured for personal purposes by the participants in the very network groups involved in its creation. Investigating the relationship through the lens of Operation Rotten Tomato, the case studying conversion, through Chapter 11 Bankruptcy, of property qualified for recovery based on suspicion or reasonable grounds to suspect unproven wrongdoing. Implementation of the United Nations Convention Against Corruption a systemic experimentation in public policy failure, information asymmetry and principal agent problems.
\end{abstract}

Keywords: distributed ledger, grand corruption: state capture, undue influence, tailor-made law, political patronage, institutional change, public-private partnership, rule of law, sustainable development goals

\section{INTRODUCTION TO THE PROBLEM, ITS ROOT CAUSES, AND INSTITUTIONAL CONCERN}

\author{
"There are Institutions that are just not there." \\ Dr. Ngozi Okonjo-Iweala, former Finance Minister of Nigeria
}

Due to the absence of institutional capacity for receivership, receivership practice had become a significant source of destabilizing phenomenon unobservable to the institutions responsible for supervision and stability of the global financial system as an externality. Personal misconduct in this area has gone unchecked until recently.

"We have seen cases where civil society organizations (CSOs) were extremely active proposing solutions, giving ideas and where they were listened to. Cases where 
eventually", [such solutions], "ended up being captured by organizations that were devious insidious and smart about enrolling it into their own purposes."

This is a quote from the former International Monetary Fund's (IMF) Managing Director and Chair, Christine Lagarde, who successfully petitioned the IMF executive board to create the 2017 Enhanced Fund Engagement. This program mandates authority between the IMF, the World Bank Group, the UN, the Central Banks, and in-country authorities. The executive board of the IMF is the authorizing body for the 2017 Enhanced Fund Engagement. The World Bank Group, the member states of the UN, the Central Banks of those member states and the in-country authorities represented by the Attorneys General all assent to the 2017 Enhanced Fund Engagement. The Enhanced Fund Engagement is an instrument that increases the scope of the operational mandate of the IMF to increase cooperation between these groups.

The World Bank Groups' Global Forum on Law, Justice, and Development (GFLJD) Community of Practice on Insolvency and Creditor/Debtor Regimes was established by interested civil society organizations, non-government organizations, network groups, academia, official government agencies and regulatory bodies therein referred to formally as, the partners, with the purpose of analyzing the interdependencies of insolvency law, corporate law, and procedure law (WBG, 2012). These organizations provide a view into how certain relevant CSOs and their actors, practitioners, and members exploited the absence of institutional capacity necessary to fulfill the receivership term provided for within the relevant international convention(s). It also shows that they abused the GFLJD in a conflict of interest by shepherding the receivership term of the relevant international convention(s) into their own firms' insolvency practices.

U.S. President, George W. Bush, signaled that bankruptcy is a last resort and therefore not a legitimate qualified asset recovery vehicle by signing S.256 (2005-2006), the Bankruptcy Abuse Prevention Legislation. Bush disagreed with blending insolvency and law enforcement of qualified asset recovery, saying "the Law will also allow us to clamp down on bankruptcy mills that make their money advising abusers on how to game the system" (Bush, 2006). The corruption of state capture, undue influence over lawmaking, and tailor-made laws designed to ensure the interests of natural persons, legal persons, and network groups (IACC, 2020) to the detriment of the public interest have been attempted as part of receivership provision.

The Civil Law legal system, which is practiced within Europe as compared to the Common Law legal system which is not practiced inside Europe, rejected the inherently conflicted proposition of blending insolvency practice with law enforcement of qualified asset recovery. Insolvency practice is in the domain of bankruptcy while representing itself as a bona fide third party to law enforcement related qualified asset recovery, should be restricted to civil not criminal judicial proceedings regardless of whether the proceeding is being held within a Civil Law or Common Law legal system jurisdiction. The blending of that domain with criminal law and especially at the phase of allegation and accusation or indictment as demonstrated by cases referred to by the IMF is proving to transgress due process. The Civil Law legal system agreed only to the right of a third party to be heard in their effort to establish standing without permitting a direct affront by such third party to UN CAC's Article 4 whether to usurp or transgress the jurisdiction of another's sovereign territory.

This unobservable externality and personal misconduct, blending insolvency practice with law enforcement of qualified asset recovery, practiced by the above mentioned insolvency practitioners have been recently recognized by former Governor of the Bank of England, Sir Mervyn King as a here to fore unobservable externality (King, 2019), and Board of Governors of the Federal Reserve System Vice Chair for Supervision, Randal K. Quarles as personal misjudgments and misconduct (Quarles, 2020). While personally lucrative, this overreach manipulatively shepherding law enforcement of qualified asset recovery into their insolvency practice is detrimental to the maintenance of asset values. Maintaining asset values is identified by the IMF as so macro - critical that it is considered in the $13^{\text {th }}$ Draft Doha Declaration at 8. (h)

"To develop and implement adequate mechanisms to manage and preserve the value and condition of frozen, seized or confiscated assets" (UNODC, 2015). 
The former U.S. Director of National Intelligence, Dan Coates, identified the national debt as the greatest internal risk to the United States' national security when he testified before Congress in February 2018. The global spillover effect of U.S. insolvency is destabilization of the global financial system.

\title{
Learning
}

Given the global community's accelerated mandate to fund the 2030 Agenda and achieve the United Nations Sustainable Development Goals (SDGs) number 1-17 while situated on the precipice of climate disruption, the United Nations Secretary General says "[W]e have a short and rare opportunity to change our world for the better" during the COVID-19 pandemic. As stated by the IMF Managing Director, Kristalina Georgieva, "[A] crisis [is] never to be missed as an opportunity to do better." United Nations Sustainable Development Goal \#17 proposes funding the UN SDGs through revitalization of public-private partnership. Receivership practice is a vital aspect for administration of terms set forth toward implementation of the United Nations Convention against Corruption (UN CAC) and relevant model legislation from the United Nations Office on Drugs and Crime (UNODC) which is the secretariat of the UN CAC in Vienna. This paper addresses the United Nations Secretary General's Special Envoy on Financing the 2030 Agenda for Sustainable Development, who appears uniquely positioned to advocate changing course on receivership practice.

\section{BACKGROUND}

\author{
"Turn toward the problems you see." \\ U.S. President, William Jefferson Clinton
}

A problem to turn toward appeared in September 2009, igniting nearly ten years of research. This research is entitled "Accountability Asset Recovery: A Leadership and Sustainability Initiative Paper Series" and "A Practical CONCEPT NOTE for Harnessing Disruptive Forces to Evolve Best Practices to Next Practices." It was first presented as a paper in May 2017 at the 4th International Symposium on Corporate Responsibility and Sustainable Development at ESC Pau, France. As the economic value the receivership legal provision identifies became apparent, the paper was presented at conferences such as the Middle East Economics Association (MEEA) section at the Allied Social Sciences Association (ASSA) annual conference, the Western Economics Association International (WEAI), and the WEAI Issues in Financial Industry session. Opportunity to expand the receivership legal provision's relationship with digital financing distributed ledger technology arose, including at UNGA in New York and in WIF Geneva doctoral symposium on monetary innovation at block chain for the SDGs in 2018. As Alpha FTS, the researcher's technical expertise was even drawn upon by the SDGs workshop for parliamentarians during the World Investment Forum in Geneva in 2018. Then, as Alpha FTS, the researcher received an invitation to join The World Bank Group's global forum on law, justice, and development (GFLJD) in January 2020.

Alpha FTS Research \& Development in the Social Sciences, Humanities, \& Technology was dreamed up on August 30, 2016 in the Kingdom of Morocco, by the private parties Monika L. Sheldon-London, a California-born U.S. citizen who has an MBA in Leadership \& Sustainability, Master in Contemporary Diplomacy and is a student working toward the MPA at Harvard Kennedy School, and H. David Dardouri, a Moroccan-born French national who has a PhD in Mathématiques, MA II in Astrophysique and Minérale Chimie, Ingénierie, and is skilled in private corporate espionage detection. Alpha FTS was tasked with establishing "Accountability Asset Recovery: A Leadership and Sustainability Initiative" within the publicprivate partnership framework. Alpha FTS sees polytechnic engineering education specific to technology supported finance and accounting as the path forward. Its goal is to formally explore the technical demands of receivership without disposition. 


\section{MOVING FORWARD TAKES COURAGE}

Christine Lagarde called upon institutions, citizens, and private enterprise to bring about an "Age of Ingenuity," stipulating that we must have the courage to build it.

Addressing the receivership terms' systemic policy failure, Alpha FTS has spent more than 23,000 hours isolating and testing the steps outlined in both the Common Law legal system and Civil Law legal system international conventions regarding the receivership term in the real world. The opportunity presented itself as the U.S. FBI's Operation Rotten Tomato and involves four countries on three continents. This included two distinct legal systems and three versions of the UNODC model legislation (2003, 2005 and 2009) as well as differing domestic laws. This was all to answer the question:

\section{Why Is the System Failing at Recovering Assets, Securing Their Value, and Holding Onto Them?}

Operation Rotten Tomato involves approximately $\$ 3$ billion USD that has disappeared through insolvency practice. Of the $\$ 3$ billion, only $\$ 200$ went to the U.S. government when bankruptcy insolvency practitioners successfully generated a criminal proceeding initiated against a U.S. businessman within the Common Law legal system; thus blending insolvency practice with law enforcement of qualified asset recovery. The allegation of serious offence was employed to initiate a bankruptcy proceeding with law enforcement assisting the insolvency practitioners with the recovery of what was being defined as qualified assets. In order for assets to qualify for law enforcement recovery they normally would be subjected to due process and must first be proven to be illicit.

Ultimately, we discovered no serious offence existed in any of the jurisdictions involved and no assets had been proven to be illicit. The Civil Law legal system did not respond to pressures to participate in a similar usurpation and transgression of due process when the jurisdiction asserted its right to sovereignty under UN CAC Article 4.

Alpha FTS is building the capacity of institutions for receivership practice that de-emphasizes discretion and emphasizes best practice. The case study we analyzed is a disaggregation of the previously unobservable systemically destabilizing externality when in large concentration participants wrongfully blend insolvency practice with law enforcement qualified asset recovery. Our value proposition is to be delivered through co-creation of subject matter expert consulting, training, training materials, a textbook, and a training program for relevant official institutional actors.

To repeat, Alpha FTS sees a viable pathway through polytechnic engineering education specific to technology supported finance and accounting. We have already taken steps to follow international convention regulations as justice departments around the world ought to. This amount of detail has been garnered through experience and through randomized control testing (RCT) over three iterations. In other words, Alpha FTS recognized the corruption in the official system and started doing specific legal motions and providing analysis of the various things that were being done by others and the various things that should have otherwise been done when ensuring the constitutions and the Geneva Convention factor into the international convention's intended receivership term in practice, the right way. Alpha FTS has closed one case in a world with hundreds of thousands of cases of corruption in a nascent job sector among the treaty signatories aiming to fix this problem of blending insolvency practice with law enforcement of qualified asset recovery.

\section{THE MULTILATERAL PMO (PROJECT MANAGEMENT OFFICE)}

Receivership without disposition is the recognition that disposition of assets must be cordoned off from receivership practice. "Accountability Asset Recovery: A Leadership and Sustainability Initiative" proposes multilateral PMO establishment for receivership practice to address absent institutional capability. As implementation of the United Nations Convention Against Corruption (UN CAC) is being driven forward on an institution level, an in-country authority level and on the level of CSO's and network groups such as the insolvency profession, evidence from cases that involve the recovery of qualified assets proves the need for such a multilateral PMO. The Multilateral PMO is virtual; it would become the home base for 
scaling up innovation. Such a PMO would allow signatories to be managed as portfolios. It would have the capacity to synchronize, replicate, and share consensus data on a distributed ledger. This would also address the UN CAC signatory noncompliance issue.

Receivership without disposition is an effective way to attract the right workforce talent. Since the mission of the Doha Declaration Global Programme is to instill a culture of lawfulness in today's world, receivership without disposition would incapacitate those that are unhealthy for the system while inviting true integrity. It also creates a compelling narrative in contrast to that of bankruptcy as a tool to fight fraud and recover assets or the national emergency restructuring entity (ERE) (ABI, 2020). One might hasten to add behaviors including assets being disposed of for pennies or as cooperation incentives provided for in the UN CAC. If Alpha FTS were to recover the \$3 billion USD lost to Operation Rotten Tomato, it would be while tackling an intractable social ill that would benefit millions of people around the globe.

With a fifty-year lifespan for creating the next generation of jobs, the gap is receivership without disposition. The time is now for solving this problem, blending insolvency practice with law enforcement of qualified asset recovery. The multilateral PMO creates a centralized repository for qualified recovered assets, respecting each country by managing it as a portfolio (Sheldon-London, 2019, 2019, 2020).

\section{REFERENCES}

ABI. (2020). ABI's 16th International Insolvency \& Restructuring Symposium in conjunction with ABI's Cross-Border Insolvency Program. Alexandria Virginia: American Bankruptcy Institute.

Bush, G.W. (2006). Bankruptcy Abuse Prevention Legislation S.256 (2005-2006) (Section1405). Washington DC: CSPAN Retrieved from https:/www.c-span.org/video/?186395-1/bankruptcylegislation-signing

IACC. (2020). 19th International Anti-Corruption Conference. Singapore: IACC.

King, M. (2019). Mervyn King: Economic Policy in a World Turned Upside Down. Washington DC: International Monetary Fund F \& D Magazine Retrieved from https://www.imf.org/en/News/Podcasts/All-Podcasts/2019/11/23/mervyn-king

Quarles, R. (2020). American Bar Association Banking Law Committee Meeting 2020 Spontaneity and Order: Transparency, Accountability, and Fairness in Bank Supervision. Washington, D.C. Retrieved from https://www.federalreserve.gov/newsevents/speech/quarles20200117a.htm

Sheldon-London, M.L. (2019). Accountability Asset Recovery: A Leadership \& Sustainability Initiative 5th Paper Presentation in the Series. West Palm Beach Florida: Journal of Accounting and Finance, 19(7). https://doi.org/10.33423/jaf.v19i7.2567

Sheldon-London, M.L. (2019). White paper: Qualified Asset Recovery Multilateral PMO Establishment Funding Sustainable Development Goals for the United Nations Secretary Generals' Digital Finance Task Force (UNSG DFTF). New York NY: UN.

Sheldon-London, M.L. (2020). Accountability Asset Recovery: A Leadership and Sustainability Initiative. Journal of Applied Business and Economics, 22(13). https://doi.org/10.33423/jabe.v22i13.3896

Sheldon-London, M.L. (2021). Alpha FTS Submission to the UNGASS against Corruption 2021.

UNODC. (2015). Draft Doha Declaration A/CONF.222/L.6.Doha, United Nations Office on Drugs and Crime. Retrieved January 24, 2021, from https://www/unode/org.documents/congress/Documentation/Report/ACONF222_17e_V1502929. pdf

World Bank Group. (2012). Law, Justice and Development (LJD): Global Forum on Law, Justice and Development (GFLJD) Partners View. Washington DC: Retrieved from http://www.globalforumljd.com/partners-view 


\section{APPENDIX}

\section{Operation Rotten Tomato}

According to the New York Times, Robert Watson, a purchasing officer working for Kraft Foods, took a $\$ 20,000$ bribe. Watson's $\$ 20,000$ bribe was sent in the form of a $\$ 24,000$ check signed by Randal Rahal of Intramark, a New Jersey food ingredients broker. Not included in William Neuman's February 24, 2010 NY Time's story, is how on April 10, 2008 the check was carefully placed into a flat cardboard United Parcel Service (UPS) letter pack by Rahal's secretary, Mary Ann Stocker, then shipped to another UPS center in the mid-west with instructions to hold the pack until July 8, 2008 and then, once the day arrived, returned to the sender, Rahal. Watson's $\$ 20,000$ bribery check was returned to Rahal un-cashed. According to the New York Times this bribe allowed a tomato vendor to sell tainted food. Production records from the tomato processing factory prove the FBI lot \#'s 07100117 and 07100118 of the "moldy tomato paste samples" were procured during the period of time that the factory was not running due to maintenance (stop at 07100116 restart at 07100119 ) and even if the FBI did somehow obtain these so called "samples of moldy tomato paste," the factory was in the middle of a run of tomato puree that day, not tomato paste. Operation Rotten Tomato is the perfect storm of capture: state capture, institutional capture, industry capture, grand corruption, undue influence over lawmaking, and tailor-made laws spanning four countries on three continents in three languages adjudicated in two independent legal systems; involving two car chases, wrongful imprisonment, poisoning, torture, an attempted drowning, a CIA director, three Presidents, three Attorney Generals, domestic legislation on bankruptcy regulation, a sandstorm of litigation, and a fully executed and ratified international treaty. One must only read between the lines, ("do a hatchet job, Jim Boswell, on the other king of California", in Cottonocracy American agribusiness Books \& arts review published by The Economist on October 16, 2003, The King of California: J.G. Boswell and the Making of A Secret American Empire), to realize we have somehow stumbled upon an elite piracy game of epic and Biblical proportions.

\section{Bribes Let Tomato Vendor Sell Tainted Food By William Neuman}

Feb. 24, 2010

https://www.nytimes.com/2010/02/25/business/25tomatoes.html\#: :text=Bribes $\% 20$ Let $\% 20$ Tomato $\% 20$ Vendor\%20Sell\%20Tainted\%20Food,By $\% 20$ William $\% 20$ Neuman\&text=Robert $\% 20$ Watson $\% 2 \mathrm{C} \% 20 \mathrm{a} \% 20$ top $\% 20$ ingredient,its $\% 20$ products $\%$ 20into\%20Kraft's\%20plants

1.5 million Documents comprise the Operation Rotten Tomato proving state capture grand corruption by bankruptcy mills, insolvency practitioners and their lawyers in a market share growth strategy monopoly seeking cross border precedent setting adventure in public private partnership with institutions.

The Attorney General Guide Lines for Domestic FBI Operations - At the same time, it is axiomatic that the FBI must conduct its investigations and other activities in a lawful and reasonable manner that respects liberty and privacy and avoids unnecessary intrusions into the lives of law-abiding people.

Since the authority to collect foreign intelligence enables the FBI to obtain information pertinent to the United States' conduct of its foreign affairs, even if that information is not related to criminal activity or threats to the national security, the information so gathered may concern lawful activities. The FBI should accordingly operate openly and consensually with U.S. persons to the extent practicable when collecting foreign intelligence that does not concern criminal activities or threats to the national security. https://www.justice.gov/archive/opa/docs/guidelines.pdf 


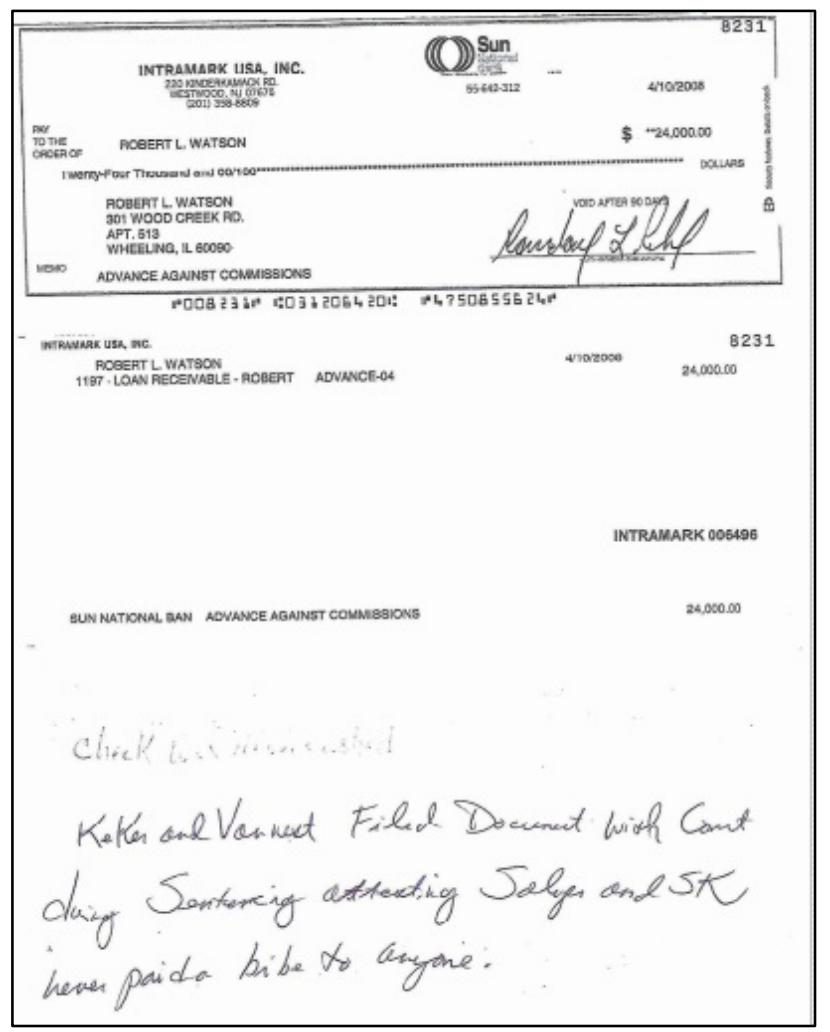

Check un-cashed, not delivered by UPS. FBI informant Rahal and Stocker read a script provided by FBI SA Paul S. Artley into the illegally wiretapped phone on 04/14/08. UPS had already shipped on 04/10/08. Rahal asks Stocker what she is sending she states a check for \$24k. Salyer was in Auckland, NZ on $04 / 10$; he couldn't have directed Rahal to do anything from the illegally wiretapped phone.

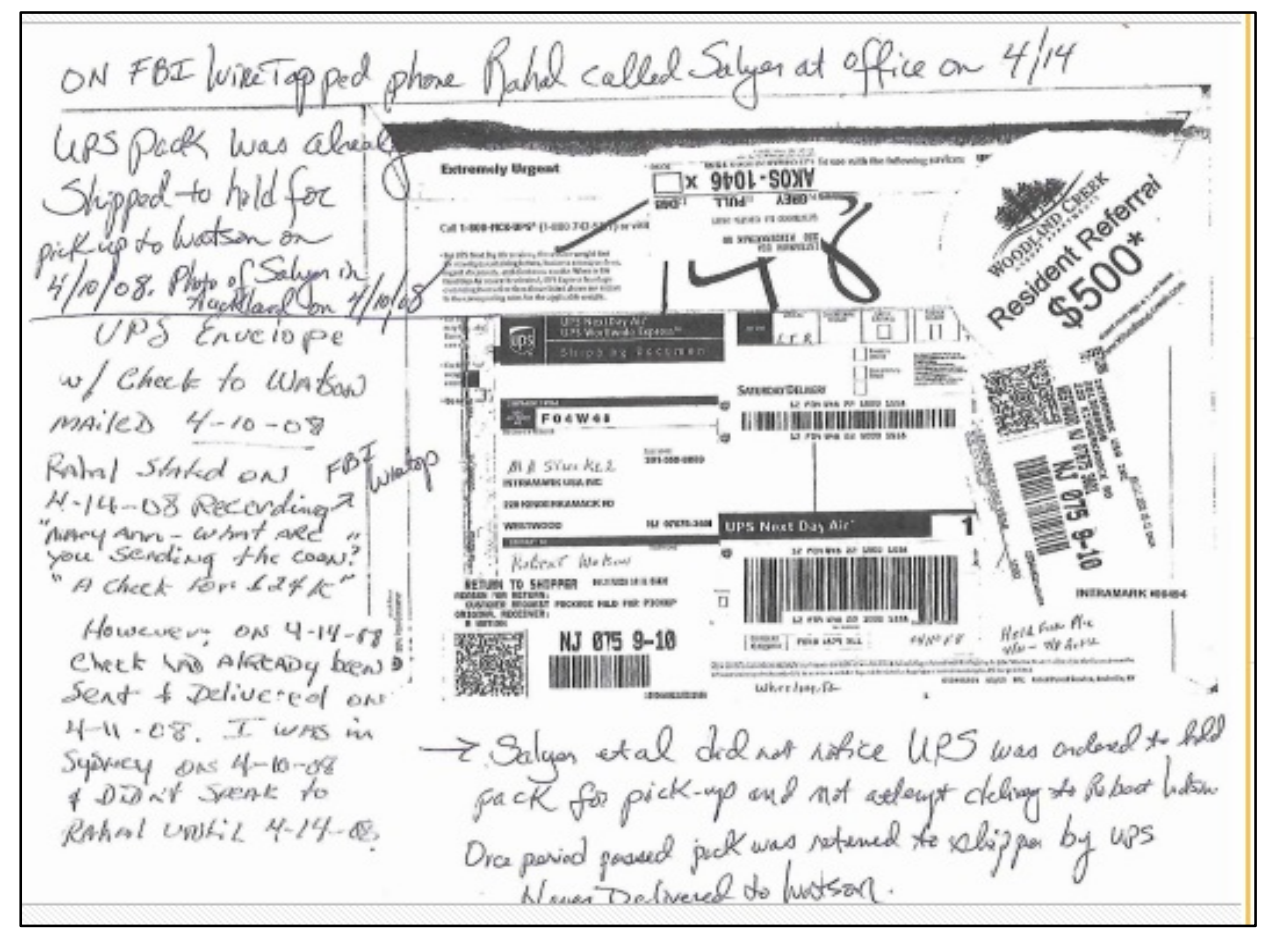



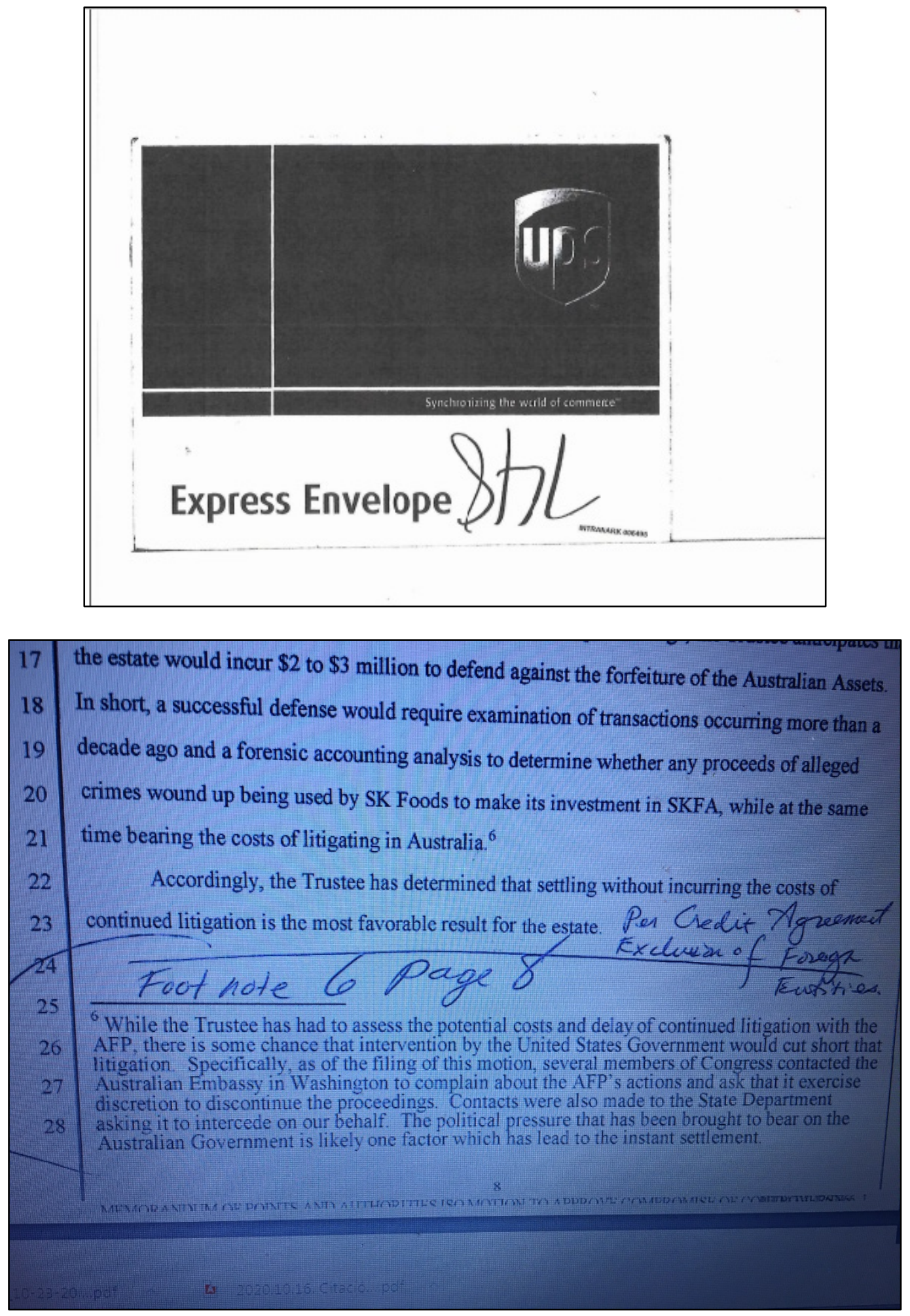

No serious offense was alleged in Australia or New Zealand. ANZ Bank appointed a receiver anyway. The court handed the case to AFP as Bradley D. Sharp of DSI/ABI alleged to the court they are proceeds of an alleged serious offense in the USA. AFP then handed over to Sharp in Adv. Proceeding 2337. Sharp 
won't ascertain whether they are "proceeds of alleged crimes." Foreign entities were not in Chapter 11; they were excluded in the Bank of Montreal 2007 credit agreement.
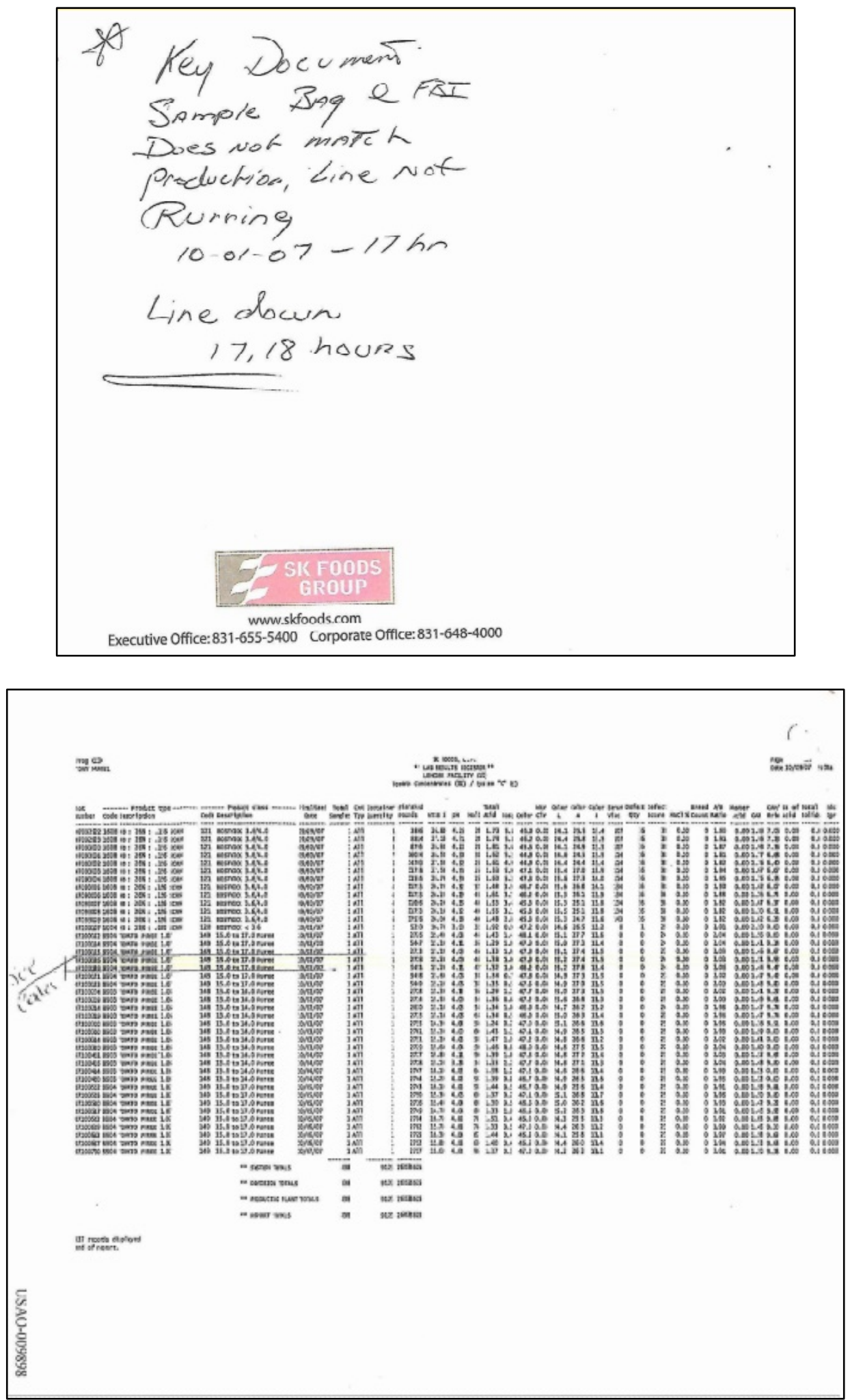


\begin{tabular}{|c|c|}
\hline \multirow{2}{*}{2} & \\
\hline & When Anthony Mamuel left Morning Star in January 2005, the company discovered that \\
\hline 4 & its once valued employee had actually been a thief - a masterful one, in fact, who managed to \\
\hline 5 & embezzle over a million dollars without anyone noticing. When Moming Star eventually canght \\
\hline . & onto Manuel's misdeods, however, it did not do what any company in its situation might do: sue \\
\hline 7 & Manuel to recover its fund. For Morning Star, Manuel held something far more valuable than a \\
\hline 8 & million dollars. The thief was now working for its main competitor SK. Foods. If Manuel were a \\
\hline & mole within SK Foods, he could wreak far greater havoc at SK Foods than he ever did at \\
\hline & Morning Star. Morning Star enlisted the FBI in its efforts and "Operation Rotten Tomato" was \\
\hline & born. Defendant's subpoena seeks to obcain evidence on Morning Star's efforts as well as \\
\hline 11 & evidence to rebut the government's recently disclosed plan to tar Defendant with Rule 404(b) \\
\hline & evidence relating to Morning Star. \\
\hline 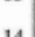 & Defendant's subpoena was properly issued, complies with Rule 17 , and does not run \\
\hline 15 & afoul of any privilege. Morning Star's three arguments to the contrary are meritless. \\
\hline $\begin{array}{l}16 \\
17\end{array}$ & $\begin{array}{l}\text { - First, Defendant's subpoena is not invalid beeause the Court did not give Morning Star } \\
\text { advanoe notice before issuing the subpoena. Morning Star was not entitled to notice and } \\
\text { its suggestion otherwise rests upon a misreading of Rule 17(c)(3). }\end{array}$ \\
\hline $\begin{array}{l}18 \\
19 \\
20\end{array}$ & $\begin{array}{l}\text { - Second, Defendant's subpoena does not impinge upon any privilege because Morning } \\
\text { Star waived any privilege when it voluntarily shared vast quantities of privileged } \\
\text { information with the government in an effort to target SK Foods. }\end{array}$ \\
\hline $\begin{array}{l}21 \\
22\end{array}$ & $\begin{array}{l}\text { - Finally, Defendant's subpoena satisfies the Nixon standard. The Court so found when it } \\
\text { issued the subpoenas in the first place and need not revisit that decision now. }\end{array}$ \\
\hline 23 & II. BACKGROUND FACTS \\
\hline 24 & The government's prosecution of Defendant had its origins in an investigation Morning \\
\hline 25 & Star commenced in early 2005. Anthony Manuel resigned from his employment at Moming Star \\
\hline 26 & on January 31, 2005 and began working at SK Foods shortly thereafter. Morning Star suspected \\
\hline & that Manuel had been secretly embezzling its funds and hired former FBI Agent Don Vilfer to \\
\hline & $\begin{array}{l}1 \\
\text { OPPOSITON TO MOTDON TOQUASH SUBPOENA } \\
\text { CASENO. 2:10-CR-0061-LKK (GGH) }\end{array}$ \\
\hline
\end{tabular}

\begin{tabular}{|c|c|}
\hline 2 & The degree to which Morning Star successfully turned the government's investigation \\
\hline 3 & into a vehicle to pursue SK Foods is laid bare in Manuel's first formal interview with the FBI on \\
\hline 4 & October $18,2006.9$ The entire interview concerns alleged improprieties at SK Foods. Manuel's \\
\hline 6 & embezzlement at Morning Star is not even discussed once. Indeed, becausc Manucl's \\
\hline 7 & wrongdoing at Morning Star had not been discussed, Mamuel's lawyer requested a second \\
\hline 8 & interview with the government in December 2006 to disclose the details of Manuel's \\
\hline 9 & embezzlement at Morning Star. ${ }^{10}$ \\
\hline 10 & Morning Star's interest in the investigation stemmed not from a desire to seek justice but \\
\hline 11 & rather a desire to eliminate a competitor. Indeed, Morning Star's motivation and its influence \\
\hline 13 & over the investigation are laid bare in an email Don Vilfer sent to Agent Artley on December 23, \\
\hline 14 & 2008. ${ }^{11}$ Vilfer provided a checklist of admissions Morning Star and its outside counsel Dale \\
\hline 15 & Camphell wanted the government to include in all guilty pleas because of their potential value in \\
\hline 16 & Morning Star's civil lawsuits. Vilfer explained, "Dale [Campbell] really wants to prove that SK \\
\hline 17 & bribed Morning Star employees while they were still Morning Star employees. That should fit \\
\hline 18 & into some kind of predicate act for industrial espionage."12 Vilfer encouraged Artley to seek as \\
\hline 19 & large a fine against SK Foods as possible - that is, unless the "fine money only goes to the \\
\hline $\begin{array}{l}20 \\
21\end{array}$ & Government ... then we do not want big fines. Something has to be left over for victims."13 \\
\hline
\end{tabular}


Cooperation between an industry competitor (represented by a former FBI supervisor hired by a law firm) and the FBI in order to fight fraud and corruption (UN CAC, 2003) is a conflict of interest. When The Morning Star destroyed SK Foods L.P., it destroyed the largest supply of organic steam peeled processed tomato products in the world. The Morning Star caustic peels its tomatoes and reintroduces a small \% of those effluents back into the finished product to avoid environmental discharge issues.

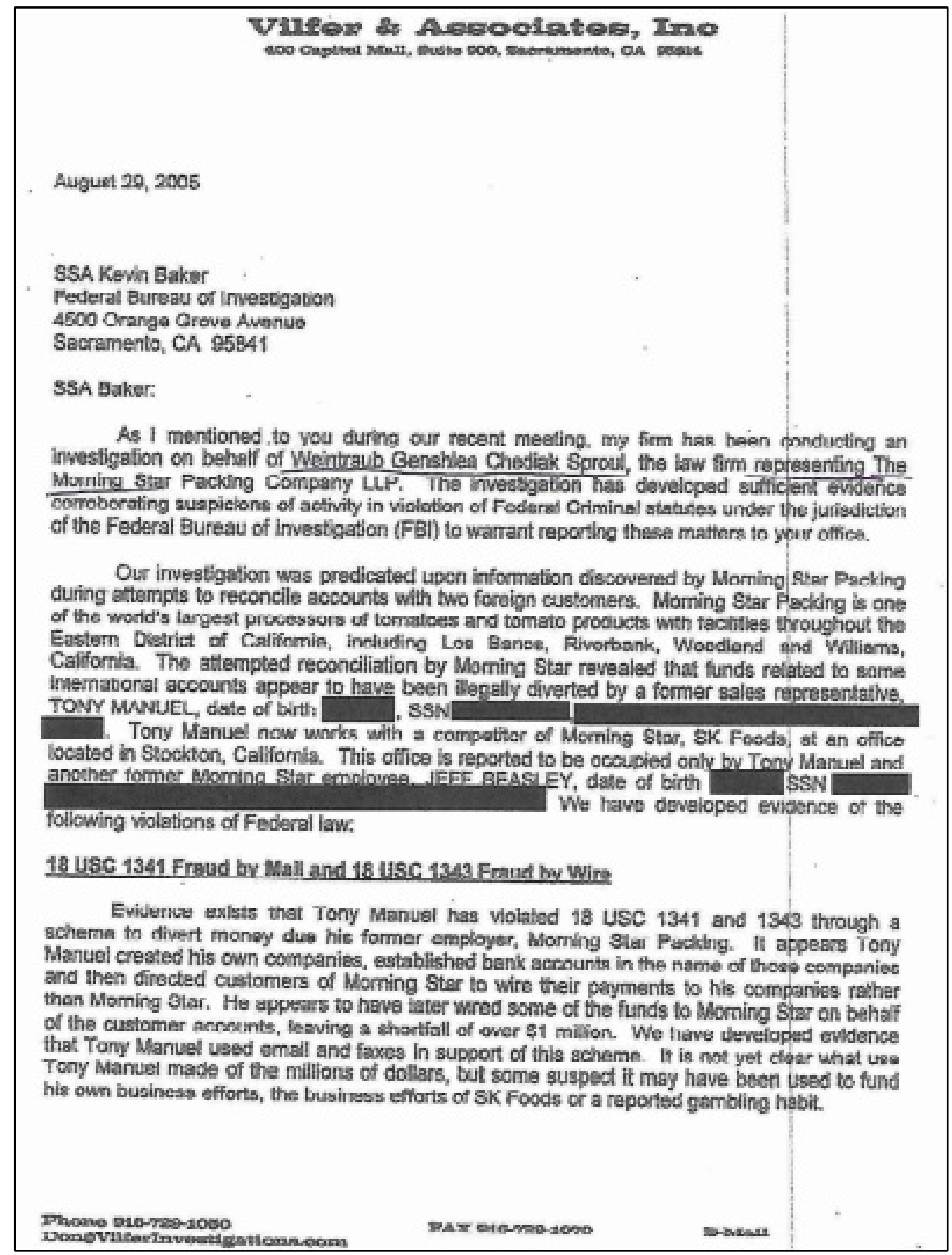

Once Vilfer and Artley get the case opened and assigned, (assigned to SA Paul S. Artley himself), the case is then reentered as Intramark/SK Foods L.P. and The Morning Star/FBI forget all about their case against Anthony Manuel. It's a growth strategy to get the market share and pursue monopoly by The Morning Star, their top customer is HJ Heinz, and their lender is Wells Fargo in service to creating shareholder value. 


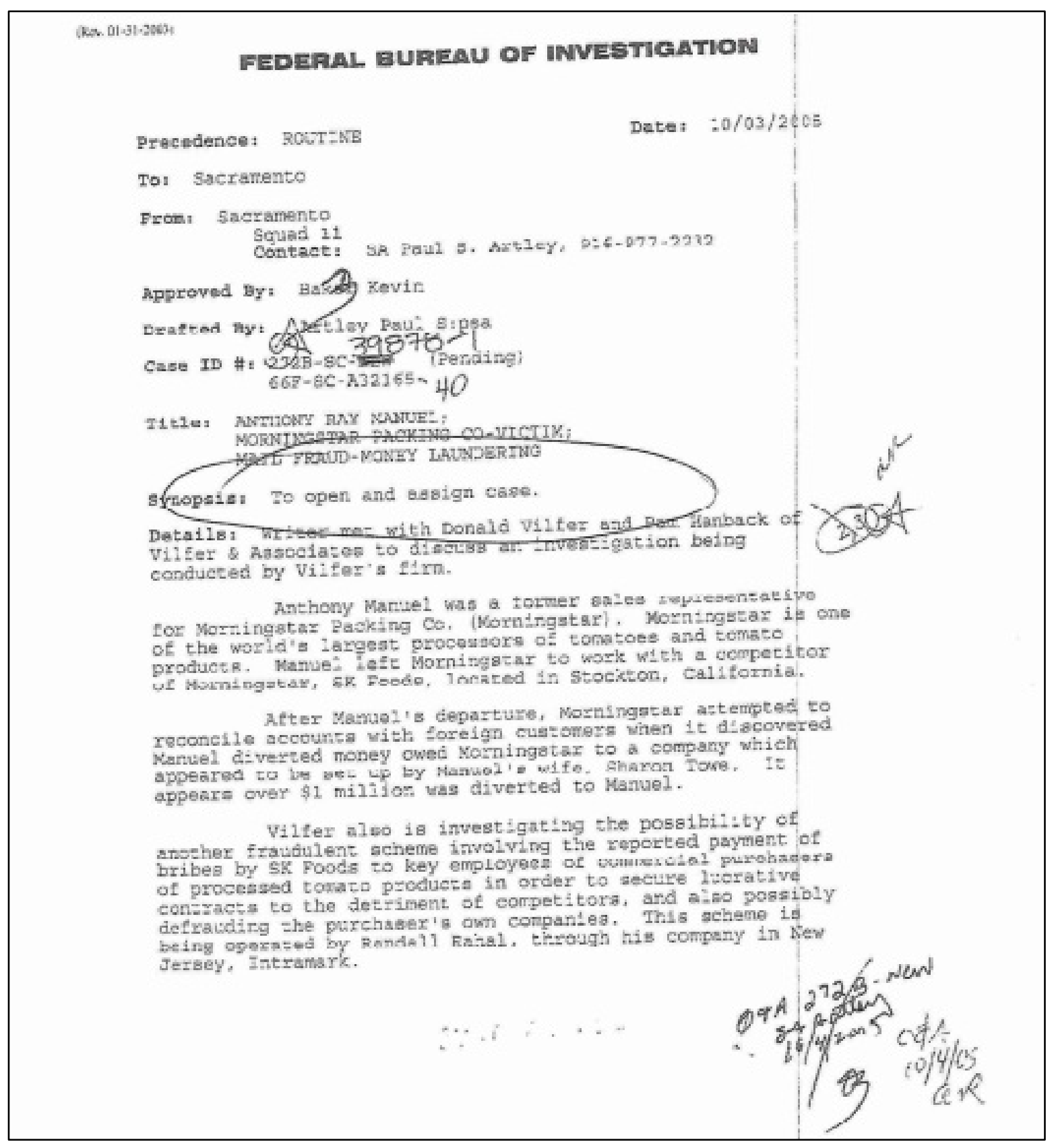

Warehouse management disagrees with US Government regarding "relabeling." They say there was no relabeling. The civil law legal system says this so-called relabeling is not a serious offense even if it had occurred. Even if US Government says Salyer agreed to it in March 23, 2012 plea agreement, relabeling is not serious offense. 

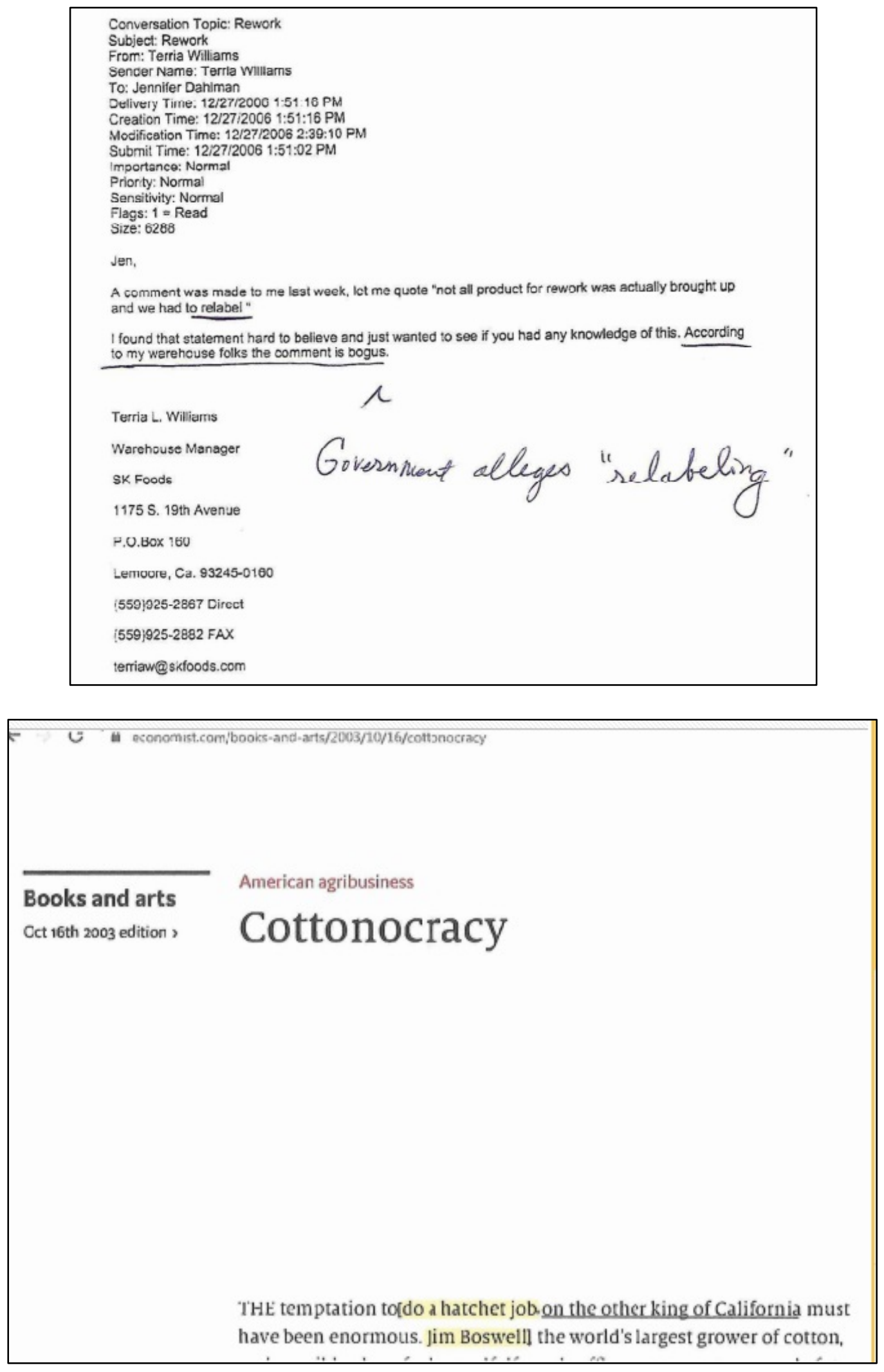

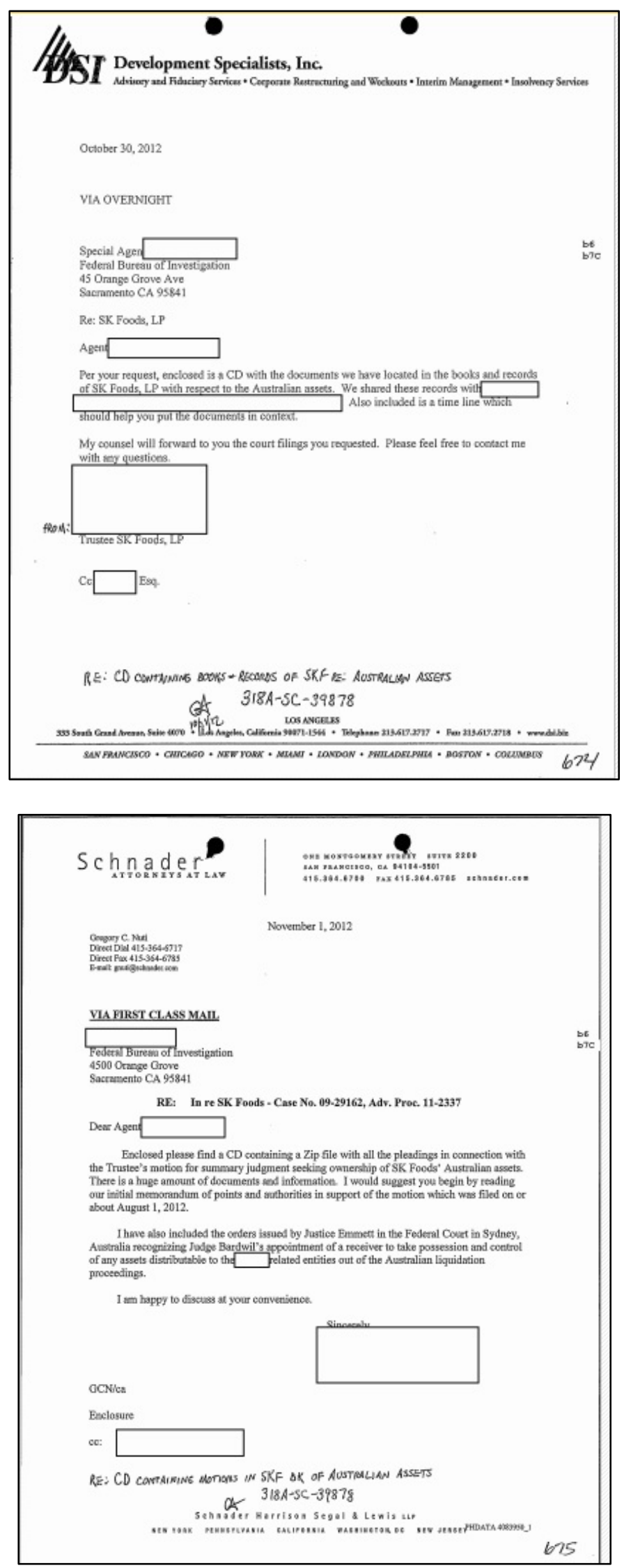

34 Journal of Leadership, Accountability and Ethics Vol. 18(3) 2021 

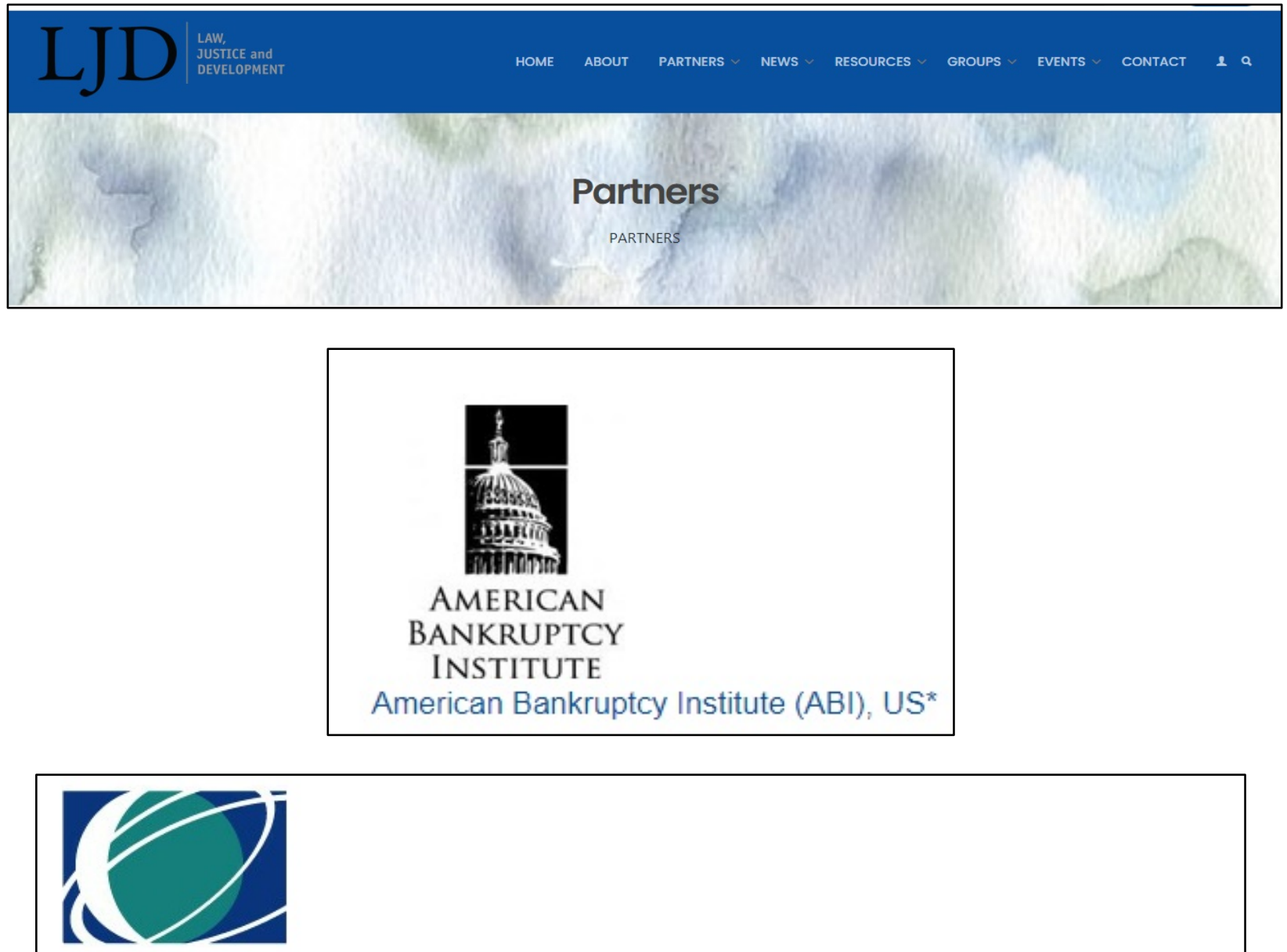

American Bar Association (ABA), US Section of International Law, US*

Founded in 1933, the Section of International Law is the leader in the development of policy in the international arena, the promotion of the rule of law and the education of international law practitioners.

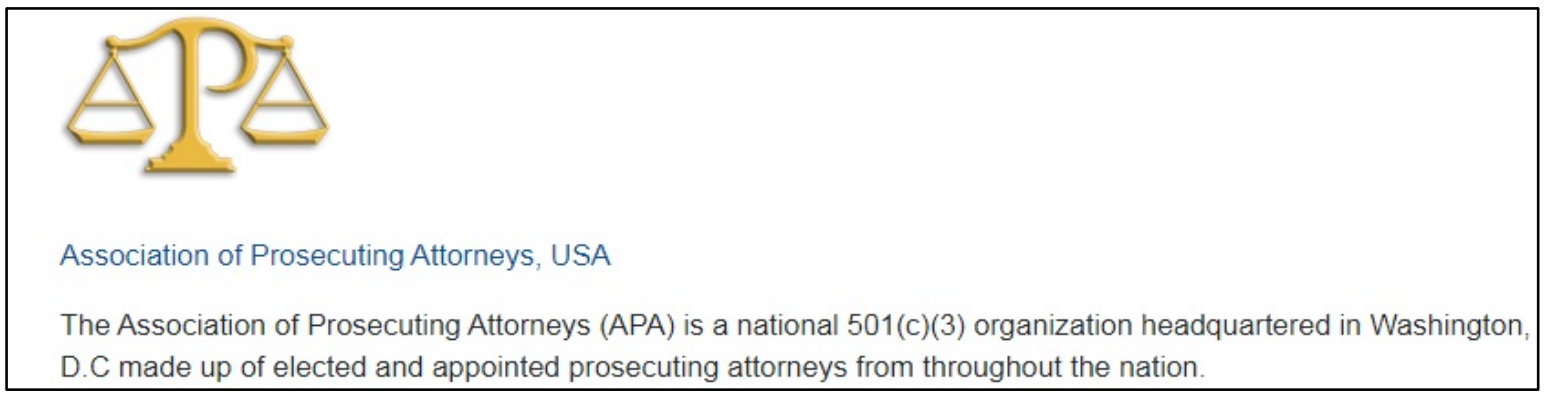

S.256 (2005-2006) (Sec. 1405) Requires the bankruptcy trustee (DOJ US Trustee Program) to move for the appointment of a trustee if there are reasonable grounds to suspect that current members of the governing body of the debtor, the debtor's CEO or CFO participated in actual fraud, dishonesty, or criminal conduct in the management of the debtor or the debtor's public financial reporting.

UNODC 2003 Model Legislation pg. 74. "For the purposes of this Act, a person shall be taken to be convicted of a serious offence if: (a) the person is convicted, whether summarily or on indictment, of the offence." 